УДК 81'33

DOI https://doi.org/10.26661/2414-1135-2021-84-19

\title{
ЛІНГВІСТИЧНА МОДЕЛЬ РІВНЕВИХ МЕТОДІВ САМОІДЕНТИФІКАЦЇ̈ НА ЗРАЗКАХ ТВОРУ ІВЛІНА ВО «ЧОЛОВІКИ У ВІЙСЬКУ»
}

\author{
Ліщенко М. В. \\ студент кафедри прикладної лінгвістики \\ Начіональний університет «Львівська політехніка» \\ вул. Степана Бандери, 12, Львів, Україна \\ orcid.org/0000-0001-5447-7785 \\ miralishe99@yahoo.com \\ Гриців Н. М. \\ кандидат філологічних наук, дочент, \\ доиент кафедри прикладної лінгвістики \\ Національний університет «Львівська політехніка» \\ вул. Степана Бандери, 12, Львів, Україна \\ orcid.org/0000-0001-6660-7161 \\ nataliia.m.hrytsiv.lpnu.ua
}

\author{
Ключові слова: \\ психолінгвістика, \\ соичіолінгвістичні \\ дослідження, описовий \\ аналіз, самоідентифікація, \\ ідентичність у наративі, \\ мова в проичесах ідентифікаиії, \\ мовні рамки, лінгвістична \\ модель, лінгвальні методи \\ самоідентифікації.
}

Самоідентифікація є досить популярним предметом досліджень багатьох психотерапевтів і лінгвістів. Щоправда, кожна праця науковців намагалась скоріше знайти нові аспекти й кути погляду на питання ідентифікації себе, ніж пояснити чи зробити грунтовне статистичне дослідження. Власна ідентичність - поняття, яке реалізується за допомогою мультивимірних невербальних i вербальних засобів і багатьох факторів, лінгвістично ж індивід проходить такий процес чи не найчастіше. До уваги варто брати не тільки безпосередній комунікативний дискурс, де активується соціально маркована ідентичність, але й внутрішні когнітивні референції та конструювання самосхем. Такі інструменти внутрішнього аналізу індивіда за допомогою самодіалогу є багатим ресурсом для визначення як поточного самоусвідомлення людини, так і іiі справжнього характеру. Завдяки таким дискурсам, як автобіографічні твори й терапевтичні монологи активуються вербальні засоби вираження потрібних самосхем, що намагаються передати в мов ленні необхідні образи власного портрета й життя. Стаття $є$ багатовимірним і багатопрофільним аналізом із новими пропозиціями щодо подальших психолінгвістичних досліджень. Основною концепцією та питанням, яке необхідно розв'язати, є створення та розгляд лінгвістичної основи для процесів самоідентифікації. Первинні й ретельно зібрані дані 3 масштабного роману Івліна Во «Чоловіки у війську» служили фундаментальним матеріалом для побудови й аргументації наших лінгвістичних моделей самоідентифікації, які виявились важливими й цінними методами для самосвідомості йзагальних лінгвістичних досліджень також. Затверджені й проаналізовані дані мають різні граматичні категорії, лексичні рівні й навіть одиниці мови. Щоправда, усі вибрані дані мають однакову прагматичну функцію - вони вказують на «я»-позицію мовця та його мислення, завдяки якому спікер чи діяч у взаємодії чи у внутрішньому діалозі може свідомо й несвідомо ідентифікувати себе в різних життєво важливих аспектах. Було визнано, що мовець використовує конкретні речення та граматичні категорії слів як інструмент для самоідентифікації як раціонально, так і ірраціонально, дозволяючи лексичному рівню мови бути корисними знаряддями не тільки для комунікативного вираження, але й для когнітивних (ідентифікаційних) причин. 


\title{
LINGUISTIC LEVEL MODEL OF SELF-IDENTITY VIA EXAMPLES OF EVELYN WAUGH "MAN AT ARMS"
}

\author{
Lishchenko M. V. \\ Student at the Department of Applied Linguistics \\ Lviv Polytechnic National University \\ Stepan Bandera str., 12, Lviv, Ukraine \\ orcid.org/0000-0001-5447-7785 \\ miralishe99@yahoo.com \\ Hrytsiv N. M. \\ Candidate of Philological Sciences, Associate Professor, \\ Senior Lecturer at the Department of Applied Linguistics \\ Lviv Polytechnic National University \\ Stepan Bandera str., 12, Lviv, Ukraine \\ orcid.org/0000-0001-6660-7161 \\ nataliia.m.hrytsiv.lpnu.ua
}

Key words: psycholinguistics, sociolinguistics studies, descriptive analysis, self-identification, identity in a narrative, language in identification processes, linguistic frameworks, linguistic model, lingual methods of selfidentification.

\begin{abstract}
Self-identification is a very popular subject of research for many psychotherapists and linguists. However, each work of scientists tried to find new aspects and angles of view on the issue of self-identification, rather than to explain or make a thorough statistical study. Since one's own identity is a concept that is realized by means of multidimensional nonverbal and verbal means and many factors, linguistically the individual goes through such a process almost often. It is necessary to take into account not only the direct communicative discourse, where the socially marked identity is activated, but also the internal cognitive references and the construction of self-schemes. Such tools of internal analysis of the individual through self-dialogue are rich resources for determining both the current self-awareness of a speaker and his true nature. Thanks to such discourses as autobiographical works and therapeutic monologues, verbal means of expression of the necessary self-schemes are activated, which try to convey in speech the necessary images of one's own portrait and life angle. This article is a multidimensional and multidisciplinary study with new suggestions for further psycholinguistic researches. The main concept and issue to be solved is the creation and analysis of a linguistic framework for self-identification processes. Primary and carefully collected data from the sound narrative of Man at Arms by Evelyn Waugh served as fundamental material for the construction and argumentation of our linguistic models of self-identification which have proved to be important and valuable techniques for self-awareness and general linguistic studies as well. It was acknowledged that a speaker uses specific clauses and grammatical categories of words as a self-identifying instrument both rationally and irrationally allowing a lexical level of language to be vessels for not only communicative expression but for cognitive (identifying) reasons too.
\end{abstract}

Постановка проблеми. Натепер поняття ідентичності розглядається в трьох різних наукових аспектах: соціальна ідентичність, психофізіологічна ідентичність та особистісна ідентичність. Усі ці різноманітні ідентичності потребують час від часу «підтвердження», атрибуції існування самих себе, оскільки «будь-яка ідентичність передбачає акти самоідентифікації: проєкцію внутрішньої особистісної структури у світ». Тому розгляд питання самоідентифікації стане не тільки плодовитим на лінгвістичні відкриття та інсайти, але й виступить багатогранною площиною для наших методологій.

Мета й завдання статті. Метою дослідження $\epsilon$ верифікація важливості самоідентифікаційних процесів як для власної когнітивної компетенції мовця, так і для його всеосяжного розвитку й, що найактуальніше, доведення цього через рівневу модель лінгвістичних методів. 
Предмет та об'єкт дослідження. Предметом нашого дослідження $є$ рівнева модель лінгвістичних методів у допомозі в питаннях самоідентифікації. Об'єктом дослідження можемо вважати всі можливі мовні одиниці, стилістичні засоби, метафоричні конструкції та інші авторські словесні методи вираження самоідентифікації.

Самоідентифікація межує зі світовідчуттям особистості, з поведінкою в соціумі й, відповідно, 3 проблемами особистісного розвитку й взаємин. Самоідентифікація тісно пов'язана із соціальними стереотипами - це свого роду міст між особистісною та соціальною психологією, між індивідуальним і соціальним. Позаяк людина $є$ ініціатором свого роду як розмови, так і різноформатних соціальних і культурних процесів, важливо, аби вона усвідомлювала й конструювала себе також [3]. Отже, самоідентифікація - це не тільки процес пошуку, формування ідентичності (конструювання), але й маркування своєї вже знайденої або тільки сконструйованої ідентичності з метою іiі збереження.

Як стверджував Еріксон (1963р.), головною функцією ідентичності є організація життя в часі. Саме завдяки опису власного Я в межах подій i середовища людина має шанс знайти свою ідентичність і цінність. У психоаналітичній літературі Спенс (1982 р.) припустив, що історії, викладені в терапії, менше говорять про буквальну історичну правду в житті клієнта, а більше про те, як клієнт передає розповідну правду про те, ким він був, $\epsilon$ та яким може бути [5].

Ознайомившись із працями Бамберга, нас стало цікавити питання: чи ідентичність і почуття власного «Я» охоплюють все життя - усі переживання, які коли-небудь були? Або вони складаються зі спогадів - i, можливо, лише окремих спогадів, які вважаються достатньо актуальними, щоб їх можна було вживати для власної ідентифікації? Однак, як показують життєві історії та наративи багатьох письменників із діахронічними характеристиками, моменти із життя або окремі спогади не обов'язково фіксовані. Власний процес ідентичності не можна розкласти на відрізки часу й передбачити їх результат. Наприклад, коли ми в поточному часі зрозуміли, що наша ідентичність, яку нам приписували інші в минулому, - це не те, ким ми $є$ насправді. Такий підсумок дає нам зрозуміти, що процес ідентифікації подібний до наративу або історії, має послідовний взаємопов'язаний перебіг стадій і когнітивних технік і повністю індивідуальний для кожного. Історії, які мовець зазвичай розповідає про себе, комплексні й фрагментарні в просторово-часовому вимірі. Своєю чергою складання особистого наративу або ж автобіографії як його варіації активує використання певних ідентичностей людини залежно від подій, середовища, часу й оточення на той момент. Саме тому успішні процеси самоідентифікації проходять за вдалої власної ретроспективи свого життя, під час аналізу себе щодо інших і за чіткого ствердження себе на кожному 3 рівнів ідентичності людини.

Самоідентифікація тісно пов'язана 3 мораллю та культурними фундаментами в нашому світогляді. Однією $з$ найбільш значущих мотивацій виконання моральних норм чи дотримання взятих на себе зобов'язань $\epsilon$ саме збереження свого ідентифікаційного статусу. Слово офіцера, слово дворянина, козак сказав, козак зробив, «так себе порядні жінки не ведуть», «ти чоловік чи хто?»приклади таких ситуацій.

У лінгвістиці термін «самопрезентація» використовується у двох основних значеннях, перше 3 яких має більш вузьке, конкретне й буквальне, а друге - ширше:

1) презентація, тобто називання свого імені (тільки імені; імені й по батькові; імені й прізвища; тільки прізвища; імені, по батькові й прізвища) і посади, соціального статусу, ролі під час знайомства або в ситуації вітання з малознайомою людиною;

2) комунікативна (в тому числі вербальна) стратегія управління враженням про того, хто говорить адресату [4].

Друге розуміння самопрезентації (самопрезентація 2) зближується з ії розумінням в психології та соціології, - це комунікативна стратегія, метою якої $є$ управління враженням адресата, формування думки про себе за допомогою вербальних і паравербальних засобів. Найчастіше йдеться про позитивну самопрезентацію, однак не виключена й мета створення несприятливої думки про себе через заперечне віднесення себе до певної групи чи колективу.

Вербальна соціальна самоідентифікація підпорядкована задоволенню найважливішої людської потреби - потреби в приналежності до групи, унаслідок чого нам стає доступна сила (цінності й ресурси) такої групи. Таке самовизначення, зарахування себе до групи може мати більш-менш демонстративний характер, тобто більш або менш сконцентрований фокус на власній ідентичності [1].

Меншу вагу такого фокусу в самопрезентації ми бачимо в разі не демонстративного самовизначення, коли управління враженням адресата відходить на другий план. Самовизначення як ціль виконує пошукову функцію відповіді на питання «Хто я?» та зустрічається переважно в текстах особистого характеру (щоденники, записні книжки, спогади), в найбезпечнішому комунікативному акті, особистому спілкуванні, а також у відповідях на відомий тест М. Куна й Т. Макпартленда «Хто я?». 
Вага самопрезентаційного фокусу підвищується в самовизначеннях «мимохідь»; основна мета полягає не у створенні образу мовця, а в переконанні адресата в чому-небудь. Це може бути функція пояснення та приєднання до авторитету певної групи: «Ми, сертифіковані психологи, радимо не ігнорувати часті й регулярні питання у своєму мозку». Поширене також окреслення меж своїх повноважень: «Я як депутат Верховної Ради обіцяю проконтролювати це питання» або ж «Не нам, простим вчителям, судити дитя та їх батьків». Дискурсивний простір самовизначень «мимохідь» - це виробнича, ділова, професійна мова, дискурс телешоу, а також сімейна комунікація.

Кожна особа має декілька самосхем, неусвідомлено кодованих у репертуарі, і одиниці такого репертуару можуть бути активовані в частині притягання метафори push-pull-revide (Горовіц, 1998 р.). Сам - це стан, організований активацією певної Я-схеми. Він може містити усвідомлений досвід ідентичності, пов'язаний 3 атрибутами такої схеми. Самоорганізація - це загальна збірка самосхем, у той час, як ідентичність - це свідоме або інтуїтивне відчуття однаковості 3 плином часу. Самосхеми містять сценарії, майбутні наміри людини, iї очікування щодо самореалізації та основні цінності в житті. Такі автосхеми функціонують як когнітивні карти; спрощення деталей у стосунках і ставленнях. Схеми, як і інші карти, можуть додавати минулу інформацію до обробки поточної інформації. У кожної людини є репертуар автосхем, які сплять у сховищах пам'яті; будь-яку одну або декілька із цих автосхем можна активувати для організації інших аспектів обробки інформації. Активні схеми «Я» впливають на поточне відчуття особистості людини. Альтернативні самосхеми (активовані) можуть змінити стан душі людини. Такий зсув змінює психологічне самовідчуття та соціальну самопрезентацію (Стерн, 1985 р.). Щоб підбити підсумок: досвід ідентичності $\epsilon$ організованим шляхом активних самосхематизацій. Самоорганізація - сукупність власних Я-концепцій і самосхематизацій - не обов'язково $є$ цілісною та послідовною організацією. Люди відрізняються тим, наскільки добре вони гармонізують такі частини й наскільки добре вони засвоїли реалістичні й концептуальні навички саморефлексії для вирішення протиріч між частинами себе [8].

\section{Дослідження.}

Лінгвістично дослідити методи самоідентифікації може бути просто, адже ми виражаємо себе в мовленні й в активних обмінах інформацією 3 іншими в розмовах чи виступах. Але в таких аспектах ми маємо можливість розглянути тільки соціальну ідентичність або ж соціальний варіант особистості, що має право бути як правдивим, так і штучно сконструйованим спікером [1].

Для безпомилкового аналізу різних способів вербальних і невербальних, прямих і дотичних самоідентифікацій буде розумно розділити ці лексичні й метафоричні групи за рівнями ідентичності людини. Власне, така лінгвістична модель буде називатись Рівневою. Попередньо вона матиме радіальний рівневий вигляд зі спадальним розташуванням рівнів ідентичності від об'єктивної оцінки себе до суб'єктивної.

Такий порядок розташування рівнів наших ідентичностей було обрано після опрацювання статистичних даних українських словників і класичних видань, котрі показали, що людина як носій мови вбачає ядро своєї свідомості в ідентичності еволюційно-видовій, тобто у твердженні щодо себе «Я - людина» [2].

3 такого приводу наша орієнтовна модель буде мати початок саме 3 Еволюційного Рівня. Слід зазначити, що, ідентифікуючи себе «людиною» або одним із «людей», мовець відносить себе до категоpiї людського біологічного виду й претендує на всі права й характеристики, які мають homo sapiens. Щоправда, навіть тут, визначаючи себе людиною або навпаки запереченням, мовцям властиво в більшості випадків вдаватись до глибинного метафоричного значення, аніж до чергового уточнення фізіологічних ознак. Наприклад, у фразі: «Я і $є$ справжнісіньким м'ясом» головний герой твору відкидає будь-які інтелектуальні ознаки людського роду, наголошуючи, що на видовому рівні він ніщо більше, ніж фізично-біологічний об'єкт на рівні 3 тваринами, який не заслуговує на рівень життя та розвитку людини звичайної.

Наступним рівнем, де людина здатна безпомилково ідентифікувати себе, виступає Сімейно-клановий рівень. На такому етапі лінгвістично найбільше досліджено мовні вирази щодо родинних зв'язків, сімейних ролей та інших конструкцій із власними іменами, присвійними прикметниками й так далі. Серед проаналізованих із твору ми можемо знайти такі вирази: «я вже давно не хлопчик», «Гаю, будь людиною свого віку» або ж «перший чоловік Вірджинії Трой», «чоловік, який не скоює гріха 3 колишньою дружиною». Вони вказують на приналежність до діахронічно визначного соціального кола, що наділяє ролями попередника-наслідника 3 віковими й рольовими характеристиками. Перш ніж знайти й ідентифікувати себе в соціумі, людині варто починати з таксономічної групи своєї сім'ї та родини, що робить такий етап важливим і відповідальним для формування майбутніх ідентичностей упродовж життя.

За ним слідує Статевий Рівень, де ідентифікація не складає великих зусиль, але відіграє психофізичну роль в житті людини, позаяк у 
соціальних установках існує групування та лейбування ролей саме за статтю людини. Розмірковуючи про поняття гендер як про виставу, дослідники мови й гендерів, як правило, спираються на важливу роботу Батлера (1990р.), який зображує жіночність і маскулінність як ідентичності, що досягаються, а не як аспекти власного Я, котрі $\epsilon$ суттєвими. Поняття Батлера про «відігравання ролі» демонструє, що статева належність виробляється за допомогою культурно пов'язаних дій, включаючи мову, одяг та інші форми самопрезентації. Батлер стверджує, що ми виконуємо роль своєї статі, часто несвідомо, через повсякденні дії [7]. Ми займаємось діями, такими як нанесення макіяжу або одягання сукні, знову й знову, проте поки ми не розглянемо їх як дію напоказ, вони здаються нам досить природними. Дослідники мови й статі широко використовували концепцію відігравання ролі, оскільки вона допомагає пояснити важливість мови для зміцнення та проєктування гендерної ідентичності.

Також досить цікава праця Обара й Еткінса продемонструвала, що мова не $є$ виключно жіночою чи чоловічою, а навпаки свідчить про те, як стать перетинається з іншими написами ідентичності, такими як соціальний клас і професійний статус, у розмовній взаємодії [10]. Хоча робота підкреслювала той факт, що стать не $є$ невід'ємною властивістю, а натомість наслідком гендерної соціалізації жінок (і чоловіків), вона продовжувала спиратися на уявлення про чоловіків і жінок як однорідних (імовірно, білих, гетеросексуальних) цілих.

Виділені нами знахідки слугують як приклади вираження статевої ідентичності героя. Варто зазначити, що у своєму мовленні він не висував прямої статевої самовизначеності, щоправда, можемо бачити кілька модальних конструкцій у непрямому наголошені на цьому. До прикладу, колишня дружина його описує як «навіжену свиню без жодної ознаки сексуальності», акцентуючи на відсутності будь-якого статевого компонента водночас. Це дає нам зрозуміти, що роль чоловіка, яку вона звикла або очікувала сприймати, він не відігравав, а підкреслила вона це, додаючи негативну й емотивно забарвлену алегорію 3 навіженою свинею. В інших випадках зустрічаємо також звертання «старий дядько Краучбек - справжній джентльмен», що звучало на адресу нашого героя та лестило його соціальному статусу в колективі війська. Тут відбувається прирівнювання його до групи джентльменів, які мають позитивне високе соціальне значення. І підкреслюють його фамільярним і стилістично унікальним звертанням «дядько», що своєю чергою лише підсилює віднесеність до чоловічої статті. Вартує уваги його власне самоствердження: «Я не такий поганий чоловік, як Огастес». Це засвідчує нам про активацію чоловічої ідентичності проти такого ж представника гендеру, але головним тригером (чинником активації) виступає ситуативна картина $з$ урахуванням жінки, яка є протилежним гендером. Упродовж всього наративу головний герой не активує свою статеву ідентичність, саме окрім випадків із діями сексуального характеру або ж в контексті ототожнення себе з іншими конкурентами (схожими за статусами чоловіками). Зазвичай такі конструкції вміщують і поєднують у собі соціальні аспекти й родинні зв'язки, адже в семантичному полі «рід» усі елементи діляться на два гендери.

Опісля ми схарактеризували четвертий рівень - національно-територіальний. 3 лінгвістичного погляду на такому етапі людина позиціонує себе як «Ми» й відносить себе до одного цілого народу або ж етнічності, яка незалежно від кількості $€$ одним цілим культурно й історично. Етнічна ідентичність складається 3 багатьох факторів, поєднань, що виникли історично та є унікальними для кожної нації. Вирішальними факторами $є$ мова й заснована на ній культура. Іншими факторами, які $є$ частиною цього, $є$ спільна релігія, традиції, колективна самосвідомість, колективне протистояння іншим націям (Rannut et al., 2003 р.). Ернест Геллнер - автор теорії націоналізму (1983р.), в якій основою національної приналежності крім спільної культури також $є$ прийняття один одного як належного до однієї групи [12]. На думку Е. Геллнера, національна ідентичність полягає не лише в приналежності до групи з об'єктивно визначеними характеристиками, а скоріше в колективній концепції як цілому образі такої групи. Етнічна ідентичність також грунтується на мові, адже культуру неможливо зберегти без мови. Тому мовна ідентичність або лінгвонім відіграє значну роль у формуванні етнічної ідентичності (Skutnabb-Kangas, 2000 р.). Із цього можна зробити висновки, що в процесах самоідентифікації окремої людини присутні процеси ідентифікації мовців у групах чи громадах на фоні.

Позаяк національна ідентичність бере початки до появи самого мовця, вона розуміється мовцем як апріорі ідентичність, тобто спадкова. Щоправда, саме вона спричиняе конфлікти під час глобальних змін політичного життя та відіграє більшу роль у процесах самоствердження людини, ніж іiі власні когнітивні здібності. До прикладу, такі вирази, як «але я ж зовсім не квіт нації», «я хотів би помолитись за наше королівство» й «думаю, я в боргу перед своєю країною» допомагають зробити висновки, що головний герой ототожнює власну реалізацію з успіхом власної країни (королівства), де присутня відповідальність і відчуття боргу за проживання та перебування в певному національному середовищі.

Наступним рівнем, що зменшує об'єктивність, але збільшує власне суб'єктивне бачення самої 
людини про себе, є соціально-професійний рівень. Сюди ми зараховуємо категоризацію себе в різних соціальних групах, віднесення самих себе до угрупувань чи колективів за професіями й видами діяльності, за функціями в суспільстві. У такий момент можуть перетинатись кілька ідеографічних понять через різноманітні професії, кваліфікації, звання та інші ієрархічні поділи суспільства крізь віки й культури в них. Серед таких у творі зустрічаються «ви забули, що звертаєтесь до старшого за званням офіцера», «не думаю, що я належу до будь-якого прошарку» або ж «його ніколи не вважали simpatico», що зображають самоідентифікацію безпосередньо через призму норм суспільства в синхронному розpiзi. Можна висунути гіпотези щодо проблем із самоідентифікацією через неможливе співвіднесення себе $з$ будь-яким соціальним колом, а в разі віднесення - тільки заради прав і привілей для себе як представника такого соціально-професійного кола.

Шостим (останнім) рівнем самоідентичності ми вирішили розмістити Релігійно-ідеологічний. За тенденцією саме на такому рівні людина досягає успіху в самоідентифікації, розуміє свою роль і цінність як окремого індивіда, будує ідеологічну сутність свого буття та окремішності. Знайдені вирази на кшталт «я відчував спорідненість із тим, що називають il Santo Inglese», «я відчуваю себе нужденним із кількома дрібками віри», "Domine non sum dignus" (лат. Господи, я не достойний)» та інші свідчать про кілька категорій людського менталітету та поглядів різного аспекту, що й ідентифікують людину як представника релігії, течії, переконань чи вірувань. Такий етап $є$ найоб'єктивнішим i найяскравішим полем доказів, як проходить самоідентифікація у свідомості людини. Як правило, тут мовець вдається до модальних дієслів та емотивних виразів, що вказують на його вибір у життєвій позиції, на рівень контролю, який він бере на себе, і те, на скільки він вбачає себе окремим продуктом власних роздумів і ментальних концепцій.

Укладання та формування Рівневої моделі почалось із ретельного збору даних із нашого обраного наративу «Чоловіки у війську». Потім робота стосувалась занесення мовних одиниць у таблицю за категоріями наших рівнів та аналізу їх доцільності.

\begin{tabular}{|c|c|c|c|c|}
\hline соцјапьно-професіений & 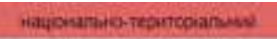 & pentihio-suronoritsa & ceonoqube-Higabst & onesivo-anavente \\
\hline ver Gye sinfatice & nowontincs ia nase koporiacteo & cropiguerictio of 11 Sarto ingese' & 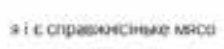 & 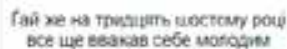 \\
\hline sid were hoxto me sanewms & ate a x me sot hath? & ane a $\times$ ne kbst malui & & a crapuan \\
\hline $\begin{array}{l}\text { Thui re nanexas po wachoro } 3 \\
\text { wox coimis }\end{array}$ & & 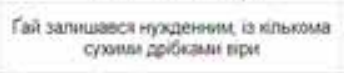 & & 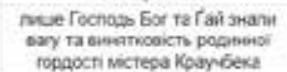 \\
\hline & & 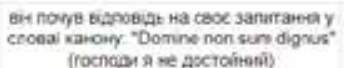 & & \\
\hline
\end{tabular}

\section{Рис. 1. Витяг із таблиці мовних одиниць за класифікацією Рівні ідентичності}

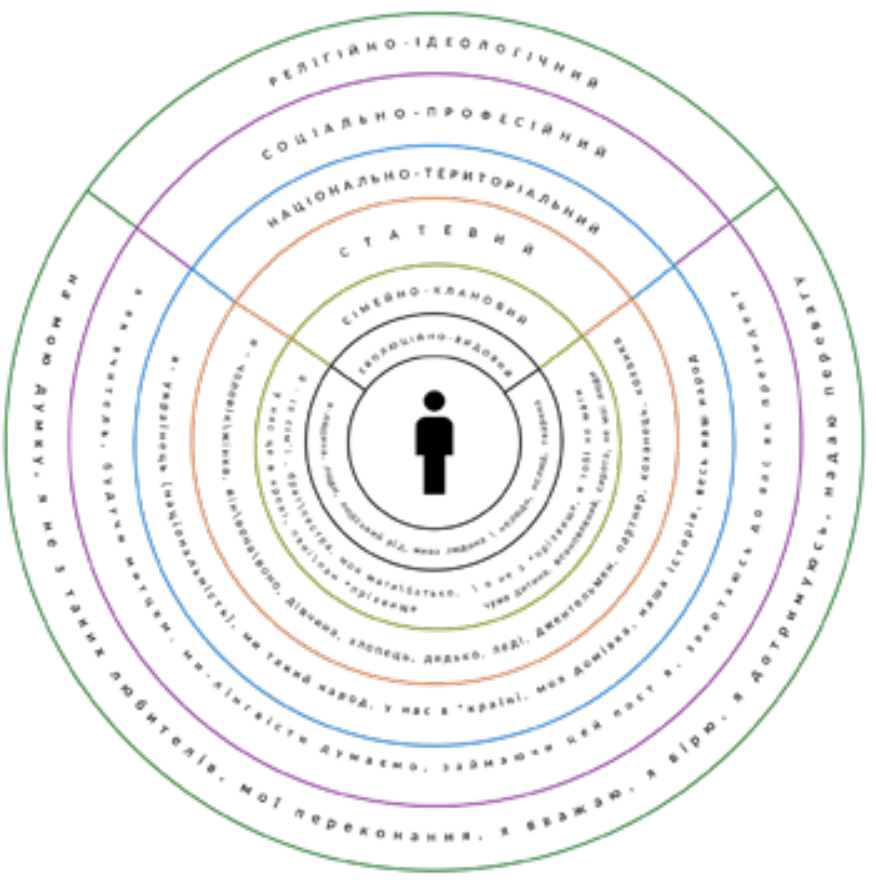

Рис. 2. Рівнева лінгвістична модель самоідентифікації
Завдяки зібраним даним стало можливо знайти закономірність і поступовість у самоідентифікації героя. Після цього доречним виявилось сформувати схематичну модель для подальшого використання та репрезентації даних. Методом уявного моделювання та схематичних замальовок рівнева модель набула радіального вигляду 3 людиною як основним героєм у центрі. Вона виступає головним діячем і критиком у власному наративі, а також будівником своїх ідентичностей. Як вже було зазначено, процес ідентифікації побудований, відштовхуючись від об'єктивного центру (хто я?) до максимально суб' єктивних та авторських конотацій для власної ідентичності.

Отже, завдяки обраній методології за рівнями ідентичностей людини нам вдалось класифікувати мовні одиниці й когнітивні схеми індивіда рівнево й виокремити головні лінгвістичні маркери для кожного. Можемо також зробити висновки, що в монологах чи самозвертаннях людина 
верифікує свій соціальний рівень ідентичностей, а на противагу в комунікаціях та інтеракціях мовцю властиво перевіряти свій ідеологічний i сімейно-клановий рівні, адже він керується непрямою самоідентифікацією в більшості випадків. Так, щоб переконатись у власній цінності й незалежності як індивіда, мовець скоріше буде використовувати впевнені об'єктивно визнані в соціумі ідентичності, такі як професія, сімейний статус та етнічна приналежність. Щоправда, свій погляд на світ і релігійно-ідеологічні концепції будуть радше предметом дискусії сам на сам або ж у самоаналізі й перегляді своєї поведінки. Не менш важливим результатом дослідження $є$ те, що рівні також тотожні до рівнів емоційного навантаження, а це означає різний емоційний вклад і переживання на кожному рівні ідентичностей. Звісно, у кожної людини своя ієрархія рівнів, але можемо зробити припущення за статистичними даними, що еволюційно-видовий рівень «Я - людина» має чи не найвагоміший вплив на настрій і психіку людини. Це відбувається в наочному прикладі, коли мовця позбавляють ідентичності «людина», цим самим забираючи основні потреби й ознаки від нього, що знижує самооцінку й відчуття себе у свідомому ракурсі. Позаяк рівні загальновикористовувані й стосуються кожного з людей як мовців, така модель буде корисна й для власного використання в самоаналізі й згодом успішної самоідентифікації.

Напрацювання також ініціюють дослідження в соціолінгвістичному й психолінгвістичному аспектах і стануть підгрунтям для розгорнутих лінгвістичних фреймворків у процесах самоідентифікації.

\section{ЛІТЕРАТУРА}

1. Лаппо М.А. Самоидентификация: семантика, прагматика, языковые ресурсы. Новосибирск : Издательство Новосибирского государственного педагогического университета, 2013. $180 \mathrm{c}$.

2. Лаппо М.А. Лексические средства описания идентичности. Вестник Томского государственного университета. Филология. Новосибирск, 2011. № 2 (14). С. 21-32.

3. Щербаков М.А. 7 путешествий в структуру сознания : Теория и практика развития личности. Москва : Издательство Новая Публикация, 1998. 288 с.

4. Bamberg M. Narrative discourse and identities. Narratology beyond literary criticism / Eds. J.C. Meister, T. Kindt, W. Schernus, M. Stein. Berlin, Germany : Walter de Gruyter, 2004. P. 213-237.

5. Bucholtz M, Hall K. Identity and interaction: a sociocultural linguistic approach. Discourse Studies 7 (4-5). London: Thousand Oaks, 2005. P. 585-614.
6. Edwards J. Language and Identity. An Introduction/ J. Edwards. Cambridge : Cambridge University Press, 2009. P. 322.

7. Fischer W., Goblirsch M. Biographical structuring: Narrating and reconstructing the self in research and professional practice. NarrativeState of the art / Ed. M. Bamberg. Amsterdam, The Netherlands : John Benjamins, 2007. P. 37-46.

8. Freeman M. Rewriting the self. History, memory, narrative. London, UK : Routledge, 1993. 120 p.

9. Goodson I. The story of life history: Origins of the life history method in sociology. Identity: An International Journal of Theory and Research. 2001. No. 1. P. 129-142.

10. Hozhabrossadat S. Linguistic Identities: How Code-switching and / or Code crossing help constructing solidarity or otherness in multilingual societies. Inter. J. Eng. Lit. Cult. 2015. No. 3 (6). P. 194-198.

11. Kihlstrom J.F., Cantor N. Mental representations of the self. Advances in experimental social psychology / Ed. L. Berkowitz. Orlando, FL : Academic, 1984. P. 1-47.

12. Omoniyi T. Hierarchy of Identites. The Sociolinguistics of Identity / Ed. G. White. London : Continuum, 2006. P. 11-33.

13. Skutnabb-Kangas T. Language and SelfDetermination. Self-determination. International perspectives / Eds. D. Clark, R. Williamson. London : The Macmillan Press, 1996. P. 124-140.

14. Wood A.M., Linley P.A., Maltby J., Baliousis M., Joseph S. The authentic personality: A theoretical and empirical conceptualization and the development of the authenticity scale. Journal of Counseling Psychology. 2008. No. 55 (3). P. 385-399.

\section{REFERENCES}

1. Lappo, M. (2013) Samoidentyfikatsiya: semantyka, prahmatyka, movni resursy [Selfidentification: semantics, pragmatics, language resources]. Novosibirsk : NGPU Publishing House.

2. Lappo, M. (2011) Leksycheskye sredstva opysanyya identichnosti [Lexical means of describing identity], Bulletin of the Tomsk State University. Philology, vol. 2 (14), pp. 21-32.

3. Shcherbakov, M. (1998) 7 puteshestviy v strukturu soznaniya: teoriya i praktika razvitiya lichnosti [7 Ways in the structure of consciousness: Theory and practice of personality development] Moscow : TP (Sekachev) Institute of personality development, pp. 288.

4. Bamberg, M. (2004) Narrative discourse and identities. In J.C. Meister, T. Kindt, W. Schernus, \& M. Stein (Eds.), Narratology beyond literary 
criticism. Berlin, Germany : Walter de Gruyter. pp. 213-237

5. Bucholtz, Mary; Hall, Kira. (2005) Identity and interaction: a sociocultural linguistic approach. Discourse Studies 7 (4-5). London : Thousand Oaks, pp. 585-614.

6. Edwards, J. (2009) Language and Identity. An Introduction / J. Edwards. - Cambridge : Cambridge University Press. pp.322.

7. Fischer, W. \& Goblirsch, M. (2007). Biographical structuring: Narrating and reconstructing the self in research and professional practice. In M. Bamberg (Ed.), Narrative-State of the art. Amsterdam, The Netherlands : John Benjamins, pp. 37-46.

8. Freeman, M. (1993). Rewriting the self. History, memory, narrative. London, UK : Routledge, pp. 120.

9. Goodson, I. (2001). The story of life history: Origins of the life history method in sociology. Identity: An International Journal of Theory and Research, 1, pp. 129-142.
10. Hozhabrossadat, S. (2015). Linguistic Identities: How Code-switching and/or Code crossing help constructing solidarity or otherness in multilingual societies. Inter. J. Eng. Lit. Cult. 3(6), pp. 194-198

11. Kihlstrom, J. F., \& Cantor, N. (1984). Mental representations of the self. In L. Berkowitz (Ed.), Advances in experimental social psychology. Orlando, FL: Academic. pp. 1-47.

12. Omoniyi, T. (2006) Hierarchy of Identites / The Sociolinguistics of Identity / G. White (eds). London : Continuum, pp. 11-33.

13. Skutnabb-Kangas, T. (1996) Language and Self-Determination. In Self-determination. International perspectives, D. Clark and R. Williamson, eds. London : The Macmillan Press, pp. 124-140.

14. Wood, A. M., Linley, P. A., Maltby, J., Baliousis, M., \& Joseph, S. (2008) The authentic personality: A theoretical and empirical conceptualization and the development of the authenticity scale. Journal of Counseling Psychology, 55 (3), pp. 385-399. 